\title{
Assessment Of Good University Governance
}

\author{
Maya Sari ${ }^{1}$, Muhammad Qorib ${ }^{2}$, and Seprida Hanum Harahap ${ }^{3}$ \\ \{mayasari@umsu.ac.id ${ }^{1}$ \} \\ 1,2,3 University of Muhammadiyah Sumatera Utara , Jalan Kapten Muchtar Basri No. 3 Medan, \\ Indonesia
}

\begin{abstract}
This study is an assessment of Good Governance in Private Universities in Medan. This study is expected to encourage the creation of efficiency, transparency and consistency in the private colleges in the city of Medan. The parameters used in the implementation of the Good Governance in Private Universities in Medan that is using the parameters of transparency, participation, supremacy of law, accountability, and effectiveness. To obtain the necessary data in this study, researchers used data collection techniques by means of a survey. Researchers conducted by distributing questionnaires to teachers and / or employees of the Private University in the city of Medan. The results show that good governance has been applied to the Private University in Medan, and most respondents expressed approval that transparency, participation, supremacy of law or regulatory compliance, akuntabulitas and effectiveness already well underway. This is supported by the statistical results of assessment of implementation of good governance in the private university in the city of Medan that have implemented the transparency of $86 \%$, the aspect of participation of $88 \%$, this aspect of the rule of law by $84 \%$, the accountability of $51 \%$, and aspects of the effectiveness of $86 \%$.
\end{abstract}

Keywords: Assessment, Good University Governance

\section{Introduction}

University is supposed to be able to ensure that good governance can be applied at all levels of the institution of the university. Governance consists of the traditions and institutions by which authority in a country is exercised. This includes the process by which governments are selected, monitored and replaced; the capacity of the government to effectively formulate and implement sound policies, and the respect of citizens and the state for the institutions that govern economic and social interactions among them (Kaufmann et al., 2010).

The Organisation for Economic Co-Operation and Development (Pfeiffer and Jr, 1999) has also argued that "markets and competition are increasingly shaping higher education." The financial structure of the private universities also varies: governmentfunded private universities receive substantial state aid, and are subject to government control, rules, and regulations, while other private universities depend largely on tuition. In terms of governance, we know very little about the quality and wider systems since they are ignored in literature (Sen, 2016). The concept of "good governance" was originated in the early 1990s, and adopted by the World Bank. Later, it became one of the major Millennium Development Goals, addressing issues from corruption to accountability, in 2000. The term "governance" in higher education indicates formal and informal arrangements that allow universities to make decisions and take action accordingly. (ADB Bank, 2012) reports that "diverse higher education systems make it impossible and inaccurate to depict a single and unitary form of higher education governance. The variations are due mainly to differences in physical, economic, and 
social infrastructure; political inclination; and the importance of higher education in national development objectives." Additionally, the involvement of multiple actors (i.e. the underlying power relationship) has played a vital role in defining the requirements for new governance and accountability mechanisms ((Tom Christensen and Laegreid, 2007).

As for the aspect or parameter measurement of good governance and good corporate governance are very varied, including: (1) Transparency; (2) participation; (3) accountability; (4) Responsibility; (5) independency; (6) fairness; (7) the rule of law; and (8) efficiency and effectiviteness. But in this study, measurement parameters in the limit on the aspects (1) Transparency; (2) participation; (3) responsibility; (4) the rule of law; and (5) efficiency and effectiviteness.

The study was based by the desire and efforts to improve the quality of universities, especially private universities, the demands of society who are eager availability of high-quality private universities. Researchers saw that the one that can be taken to make private universities is powerful, high quality, and can develop in a sustainable (sustainability development), is through improving the quality of good governancenya. This study will practically useful for the private university in the city of Medan. The benefits and impacts arising from the implementation of good governance is to make the private university is powerful, high quality, and can develop in a sustainable manner, through the improvement of good quality governancenya so as to improve the quality of private universities in the city of Medan.

Prior research on governance, in pursuit of understanding how higher education institutions are structured and managed, is based predominantly on Western countries (McLendon, Deaton and Hearn, 2007), (Davidovitch and Iram, 2015), (Rowlands, 2011), (Matengu, Likando and Kangumu, 2014), (Pennock, Jones and Leclerc, 2004). Prior research delineates that a degree of tension between government and private higher education institutions exists due to an absence of good governance. However, the consequences of adopting the governance arrangements of private universities in developing countries remain elusive - theoretically and empirically. The question is still unanswered: how does the state interact with society to provide services, and how does the state make itself accountable to society in delivering private higher education.

\section{Literature Review}

\subsection{Management College}

Referring to Government Regulation No. 4 of 2014 on the Implementation of Higher Education and Management of Higher Education, Article 1, which referred to higher education is education after secondary education that includes (1) a diploma; (2) degree program; (3) The master program; (4) The doctoral program; professional programs; (5) and program specialists. Which, all of the programs organized by the College. Meanwhile, the college is the educational unit that organizes higher education. Higher education in the form of (1) the university; (2) institute; (3) High school; (4) technical colleges; (5) the academy; and (6) the academic community. Furthermore, it is stated that the regulation of higher education include: (1) the autonomy of universities; (2) the pattern of university management; (3) The governance of higher education; and

(4) public accountability. 
Referring to Government Regulation No. 4 of 2014, the college has the authority associated with (1) the autonomy of universities; (2) the pattern of university management; (3) The governance of higher education; and (4) public accountability.

Stakeholder universities are the various parties that have links and interests, both directly and indirectly in a college. There are three categories of customers or stakeholders colleges, namely:

1. The primary customers, the students because it has a direct influence appreciate and take advantage of higher education products and participate in the production process;

2. Customers secondary, includes management college (university leaders, lecturers and administrative staff), parents, communities, governments, donor organizations and the environment;

3. Customers tertiary, ie parties who have an interest in a university, such as: the world of work, further education institutions and the environment.

When, (Cortese, 1997) categorize stakeholder universities into two, namely:

1. Internal stakeholders - faculty, operational staff, students; and

2. External stakeholders - parents, alumni, local and regional communities, donors and the government.

The term is influenced implies (1) affected directly because appreciate and utilize the product in question as well as participate in the production and presentation; (2) are affected indirectly by the products and the production and presentation; and (3) 0 there is a change in self-influenced.

\subsection{Good Governance}

Corporate governance, when viewed from the perspective of the traditional accounting and finance paradigms (Sciences, 2007), as expressed in the agency theory, "deals with the ways in which suppliers of finance to corporations assure themselves of getting a return on their investment" (Connors, 2009). In other words, corporate governance may be defined as "the set of mechanisms - both institutional and marketbased - that induce the self-interested controllers of a company (those that make decisions regarding how the company will be operated) to make decisions that maximize the value of the company to its owners" (Denis and McConnell, 2002).

Corporate governance mechanisms are the methods employed, at the firm level, to solve corporate governance problems; however the use of these mechanisms depends on the corporate governance system prevalent in each country (Connors, 2009).

Two categories of governance (or disciplining) mechanisms are described by (Khan, 2011). The first is the external disciplining mechanism which includes takeover threats, product market competition, managerial labour market and mutual monitoring by managers, security analysts, the legal environment, and the role of reputation. The second category is the internal disciplining mechanism which includes large and institutional shareholders, board of directors, insider ownership, compensation packages, debt policy, and dividend policy.

\subsection{Applying the Principle of Good Governance in Higher Education}

The concept of Good Corporate Governance (GCG) is a breakdown of the concept of GG. GCG is one concept that is becoming a mainstream issue in the implementation of strategy and corporate good. Referring Brodjonegoro Satryo view that universities need to adopt good corporate management. Then the concept of GCG also timely and 
appropriate to apply to college. GCG itself is a concept of how good corporate governance in order to be able to survive and competitiveness.

GCG at the college is required in order to promote good behavior in managing the college that is efficient, effective, transparent and consistent with the legislation. With reference to the meaning of the corporate governance, the GUG can dimakna as structures, systems and processes used by the organs of the college as an effort to give the value of the product or process on an ongoing basis.

Furthermore, GCG policy objectives in college is that the parties involved in running the university management to understand and carry out the appropriate functions and roles of authority and responsibility. Parties whose role includes the Board of Trustees, Board of Trustees, the Senate, the Rector and the Vice Rector, the committee (if any), head of the bureau, dean and vice dean, structural officials, teachers, leaders and employees.

Muhi illustrates the application of the principles of GUG on governance in higher education:

a. Transparency. College as an industry, is responsible for the obligation of information disclosure and providing information to stakeholders, so that the position and corporate management (college) can reflect the real conditions and expectations of the college in the future. In this context, more Muhi lays on (1) the transparency of the decision-making process; (2) transparency to partners; and (3) the transparency of employee performance evaluation;

b. Self-reliance. With respect to the independence, the rector, trustee, and the senate have independent views in every decision taken. In addition, it is also possible to obtain advice from independent consultants and consultants to support kelancara legak rector;

c. Accountability. To uphold accountability, a clearly defined functions, implementation and accountability of all organs in the organization, so that the management of the institution are effective. In this context, the more a concern related to the aspect of accountability in the delivery of financial statements, and the aspect of accountability in human resources;

d. Accountability. Universities should always give priority to suitability in the management of the college according to perundanguundangn rules applicable and the principles of healthy and qualified institutions. Each section / unit had the duty and function of each is clear, with the allocation of respective responsibilities are clearly stated in the college of regulatory policy;

e. Equality and Fairness. To meet the aspects of equality and fairness in the delivery of information, universities can applyequal treatment to the entire academic community. Both the fairness in terms of the relationship with the academic community, the fairness of the procurement of goods / services, the fairness of the information, and other fairness.

GUG in the measurement or assessment, this study refers to Dadang Solihin (2007), that there are four aspects that need to be measured in the GG, namely accountability, supremacy of law, transparency, and participation by adjusting the college management context. 


\section{Research Methods}

This study included research and development (development research) are resulted in the development model of good governance as an effort to improve the quality of private universities making quality private universities. This research was conducted at a private university in Medan.

This research approach is descriptive quantitative research. In the context of this study, the researchers intend to describe the phenomenon or state-principle is the application of the principles of Good Governance (GG) at a private university in the city of Medan. The population in this study were teachers and employees of private universities in the city of Medan. The sampling technique is to use 5 times the indicators of 205 respondents from the private university in the city of Medan.

In this study, the data used is qualitative data and qualitative. To obtain the necessary data in this study, researchers used data collection techniques by means of a survey. Which is a survey research by taking a sample of the population and the questionnaire as a data collection tool staple.

In order to get the data through a survey, researchers conducted by distributing questionnaires to teachers and / or employees of the private University of the city of Medan. Data collection techniques used in this study includes observations participation / observation, study of documentation, interviews to stakeholders and giving questionnaires to the relevant parties.

\section{Result And Discusion}

\subsection{Aspects Transparency}

Transparency is described by three indicators were clarified through 9 item questionnaire statements in this research, including (1)transparency in the delivery of information; (2) Media delivery of information (Website), manuals, SOPs, bulletin boards, print \& electronic goods; (3) The effectiveness of information delivery.Here are the results of a survey on the transparency aspects: the value of transparency on the question in point 1 is 822 or $90 \%$ of the respondents agreed that the college manyampaikan information both electronically and non-electronically up-to-date and complete. Then the value of the question that clause 2754 or $82 \%$ of respondents expressed approval when colleges have a website or websites as median spread of information and communication. Value of questions point 3 is 725 or $79 \%$ of respondents expressed approval if Navigation college website easily get the required information is complete and effective. The value of point 4 of the question that is 808 or $88 \%$ of respondents expressed approval when colleges have various guidelines and regulations for service delivery for higher education. The value of the grain question, namely 5801 or $88 \%$ of respondents expressed approval if colleges have System and Standard Operational Procedures on academic and non academic services to students. The value of the item question 6 which 818 or $89 \%$ of respondents expressed approval if universities submit information about System and Standard Operational Procedures financial management to stakeholders (internal stakeholders) in a transparent manner. The value of the item question 7 that 821 or $90 \%$ of respondents expressed approval if universities submit information about financial pengelolahan accountability report to stakeholders (internal stakeholders) periodically. The value of the question number 8 yaitu 751 or $82 \%$ of respondents expressed approval if universities submit information 
about System and Standard Operational Procedures openly human resource management. The value of the item question 9 yaitu 778 or $85 \%$ of respondents expressed approval if universities submit information about System and Standard Operational Procedures of procurement of goods / services to the public openly. The value of the question number 8 yaitu 751 or $82 \%$ of respondents expressed approval if universities submit information about System and Standard Operational Procedures openly human resource management. The value of the item question 9 yaitu 778 or $85 \%$ of respondents expressed approval if universities submit information about System and Standard Operational Procedures of procurement of goods / services to the public openly. The value of the question number 8 yaitu 751 or $82 \%$ of respondents expressed approval if universities submit information about System and Standard Operational Procedures openly human resource management. The value of the item question 9 yaitu 778 or $85 \%$ of respondents expressed approval if universities submit information about System and Standard Operational Procedures of procurement of goods / services to the public openly.

\subsection{Aspects of Participation}

Aspects of participation dijelaskankan with 4 indicators which are then delivered in five statements, including (1) stakeholder involved in the key decision-making / policy; (2) Stakeholders involved in the planning process; (3) Stakeholders involved in policy monitoring;(4) stakeholder involved in policy formulation. Here are the results of the survey for the fourth indicator of the aspects of participation: the value of aspects of participation on the question in point 1 is 818 or $89 \%$ of the respondents agreed that the Chiefs of universities (rector / dean / head body / head of center / bureau chief /) involving other leaders (key internal stakeholders) in policies and / or making important decisions. Then the value of the question that clause 2786 or $86 \%$ of respondents expressed approval when all the university leaders (key internal stakeholders) involved in the discussion and / or planning the future direction of the college. Value of questions point 3 is 832 or $91 \%$ of respondents expressed approval when Civitas academic colleges (internal stakeholders) oversee or control the important decisions that decide the leadership of the college. The value of point 4 of the question that is 809 or $88 \%$ of respondents expressed approval when Civitas academic colleges (internal stakeholders) have channels for the expression of aspiration to the leadership of the college. The value of the grain question, namely 5803 or $88 \%$ of respondents expressed approval if Civitas academic colleges (internal stakeholders) involved directly or indirectly participate in higher education policy formulation. The value of point 4 of the question that is 809 or $88 \%$ of respondents expressed approval when Civitas academic colleges (internal stakeholders) have channels for the expression of aspiration to the leadership of the college. The value of the grain question, namely 5803 or $88 \%$ of respondents expressed approval if Civitas academic colleges (internal stakeholders) involved directly or indirectly participate in higher education policy formulation. The value of point 4 of the question that is 809 or $88 \%$ of respondents expressed approval when Civitas academic colleges (internal stakeholders) have channels for the expression of aspiration to the leadership of the college. The value of the grain question, namely 5803 or $88 \%$ of respondents expressed approval if Civitas academic colleges (internal stakeholders) involved directly or indirectly participate in higher education policy formulation. 


\subsection{Aspects of Rule of Law}

Aspects of the rule of law dijelaskankan with 5 indicators, including (1) The existence of laws related to the implementation of education steeper; (2) A system of reward and punishment clear; (3) An effective monitoring and supervision of law enforcement agencies conducted an objective, independent, and easily accessible to the public; (4) Socialization of laws and regulations;(5) Guided by the rules and regulations. Here are the results of a survey on aspects of the rule of law: the value of aspects of the rule of law on the question in point 1 is 773 or $84 \%$ of the respondents agreed that universities have adequate rules and guidelines in order to manage the college. The value of the item question 2 that is 763 or $83 \%$ of respondents expressed approval if the college to follow the rules and regulations in order to manage the college firmly and consistently. Value of questions point 3 is 765 or $84 \%$ of respondents expressed approval when universities in implementing higher education services based on and in accordance with applicable rules and regulations. The value of point 4 of the question that is 764 or $83 \%$ of respondents expressed approval when high jesting implement the system of reward and punishment in a clear, firm, fair, and transparent. The value of the grain question, namely 5775 or $85 \%$ of respondents expressed approval if the academic community colleges (internal stakeholders) aware of and comply with the regulations and legislation in force. The value of the question, point 6 , which is 780 , or $85 \%$ of respondents expressed approval if the rules and regulations related to the provision of education be implemented effectively by the college. The value of the item question 7 that 778 or $85 \%$ of respondents expressed approval if college socialize all the rules relating to the management of higher education to all of the academic community. The value of the grain question, namely 5775 or $85 \%$ of respondents expressed approval if the academic community colleges (internal stakeholders) aware of and comply with the regulations and legislation in force. The value of the question, point 6 , which is 780 , or $85 \%$ of respondents expressed approval if the rules and regulations related to the provision of education be implemented effectively by the college. The value of the item question 7 that 778 or $85 \%$ of respondents expressed approval if college socialize all the rules relating to the management of higher education to all of the academic community. The value of the grain question, namely 5775 or $85 \%$ of respondents expressed approval if the academic community colleges (internal stakeholders) aware of and comply with the regulations and legislation in force. The value of the question, point 6 , which is 780 , or $85 \%$ of respondents expressed approval if the rules and regulations related to the provision of education be implemented effectively by the college. The value of the item question 7 that 778 or $85 \%$ of respondents expressed approval if college socialize all the rules relating to the management of higher education to all of the academic community. The value of the question, point 6 , which is 780 , or $85 \%$ of respondents expressed approval if the rules and regulations related to the provision of education be implemented effectively by the college. The value of the item question 7 that 778 or $85 \%$ of respondents expressed approval if college socialize all the rules relating to the management of higher education to all of the academic community. The value of the question, point 6 , which is 780 , or $85 \%$ of respondents expressed approval if the rules and regulations related to the provision of education be implemented effectively by the college. The value of the item question 7 that 778 or $85 \%$ of respondents expressed approval if college socialize all the rules relating to the management of higher education to all of the academic community. 


\subsection{Aspects of Accountability}

Akntabilitas aspect illustrated with 5 indicators, including (1) The existence of a Standard Operating Procedure (SOP) in higher education; (2) The mechanism of accountability of higher education; (3) The annual report; (4) The accountability report of activities; (5) The control system of higher education.Here are the results of the survey for Accountability aspects: the value of the accountability on the question in point 1 is 826 or $90 \%$ of respondents expressed approval if college mempunyi job analysis document (job description) as guidelines for employees (faculty and administrative personnel) in carrying out the task. The value of the item question 2 that is 625 or $68 \%$ of respondents expressed approval when college employees to understand and carry out their duties according to the job description job description guidelines. Value of questions point 3 is 681 or $74 \%$ of respondents expressed approval of the guidelines if the job description job description can be used as a reference in performing work or daily tasks. The value of point 4 of the question that is 793 or $87 \%$ of respondents expressed approval if the job description in the job description document in accordance with the work performed. The value of the grain question, namely 5767 or $84 \%$ of respondents expressed approval if the college has and implement guidelines for Standard Operating Procedures (SOPs) are adequate in order to provide educational services. The value of the item question 6 which 825 or $90 \%$ of respondents expressed approval if college socialize Guideline Standard Operating Procedure (SOP) to the entire academic community (Internal Stakeholders). The value of the item question 7 that 790 or $86 \%$ of respondents expressed approval if the Standard Operating Procedure (SOP) used as a guide or reference in the implementation of the tasks or services of academic and non-academic. The value of the question number 8 that is 626 or $68 \%$ of respondents expressed approval if universities (rector, faculties, institutes, centers, units) make academic performance accountability report on a periodic basis. The value of the item 9 question that is 726 or $79 \%$ of respondents expressed approval of high apabilaperguruan reports each periodic financial management accountability. The value of the grain question 10 is 815 or $90 \%$ of respondents expressed approval if all pegawa as state civil authorities make periodic reports every performance. Value of questions, point 11 is 794 or $87 \%$ of respondents expressed approval if the college as a government agency reporting his government agencies accountable for their performance (LAKIP) each year end. The value of the question items 12 that is 815 or $89 \%$ of respondents expressed approval if the unit of the supervisor / controller (SPI) in higher education public service agencies perform their role and function effectively and optimally. Value of questions point 13 is 758 , or $83 \%$ of respondents expressed approval if the financial management and performance of higher education public service agencies audited periodically SPI. Value of questions, point 14 is 828 or $90 \%$ of respondents expressed approval if SPI in college socialize / coaching / pemmgawasan in the areas of financial management, procurement of goods / services, human resource management, compliance with rules and regulations to all stakeholders (stakeholders ) College. The value of the grain question, namely 15803 or $88 \%$ of respondents expressed approval that the SPI on a college public service agencies disseminating the audit results to all stakeholders (stakeholders) college. 


\subsection{Aspects Effectiveness}

Effectiveness aspect is described with 5 indicators, including (1) The existence of a Standard Operating Procedure (SOP) in higher education; (2) The mechanism of accountability of higher education; (3) The annual report; (4) The accountability report of activities; (5) There Sistempengendalian higher education.Here are the results of a survey on the effectiveness aspects: the value of aspects of the effectiveness of the question in point 1 is 795 or $87 \%$ of respondents expressed approval if the college has a clarity of vision, target for the program, and the objectives to be achieved in the future. The value of the item question 2 that is 789 or $86 \%$ of respondents expressed approval if the college has a strategy to achieve the vision, goals, programs, and goals are formulated. Value of questions point 3 is 789 or $86 \%$ of respondents expressed approval if the achievement of the objectives, programs and planned objectives in harmony with the results. The value of point 4 of the question that is 764 or $83 \%$ of respondents expressed approval when resource use (material / budget / labor) in accordance with the impact of the implementation of programs that have been carried out. The value of the grain question, namely 5818 or $89 \%$ of respondents expressed approval if the use of the budget balanced with other programs / activities carried out.

\subsection{Aspects Transparency}

Transparency is described by three indicators were clarified through 9 item questionnaire statement in this study, include (1) transparency in the delivery of information; (2) Media delivery of information (Website), manuals, SOPs, bulletin boards, print \& electronic goods; (3) The effectiveness of information delivery. Based on the results of the study, the level of transparency in the management of universities in above average in the amount of $86 \%$. Private universities as one unit functioning education higher education providers delivering fair and quality to students by promoting the principle of non-profit and can manage funds independently to advance educational services by upholding the principle of transparency. Private universities, should be expected to be a model of how to manage a college with good governance (good governance). One of them is to promote transparency in the management of the bureaucracy. Society must be able to see how universities manage all assets and human resources that exist within the institution. Thus, the public can find out and provide feedback (monitoring) to achieve the college dream. Therefore, necessary in order to promote good behavior in managing the college that is efficient, effective, transparent and consistent with the legislation.

\subsection{Aspect Participation}

One of the principles of Good Governance is participation. Participation in question is public participation in the management or governance institutions. Aspects of participation dijelaskankan with 4 indicators which are then delivered in five statements, including (1) the key stakeholders involved in the decision / policy; (2) Stakeholders involved in the planning process; (3) Stakeholders involved in policy monitoring; (4) Stakeholders involved in policy formulation.

In this study, the aspect of participation in question is related to the involvement of stakeholder participation in terms of decision-making or policy, participation in the planning process, participation in policy control, and participation in policy formulation. Based on the results of the study, the level of stakeholder participation or 
involvement in the management of the college above average at $88 \%$. Thus, the management of private universities, in terms of participation of the campus community in particular is already relatively high. Although, this involvement should be a binding regulation. Indeed, not all stakeholders of private universities are directly involved, most of the internal stakeholders who are involved in policy formulation, policy implementation, and policy control is internal stakeholders key, for example rectors, vice-rectors, deans, vice-deans, heads of institutions, head of the center, the head bureaus, other UPT head.

\subsection{Aspect's Supreme Law}

Supremacy of law is one of the principles which must be implemented by the government in order to implement the government's good governance (good governance) for Private Universities who want to enforce tatakelolanya. Aspects of the rule of law dijelaskankan with 5 indicators, including (1) The provision of educationrelated laws and steeper; (2) A system of reward and punishment clear; (3) An effective monitoring and supervision of law enforcement agencies conducted an objective, independent, and easily accessible to the public; (4) Socialization of laws and regulations; (5) Guided by the rules and regulations.

Based on the research results, generally from various aspects that are measured above $84 \%$ of respondents expressed approval that the private university in Medan already implementing legal supremacy of the five parameters mentioned above. Based on respondents' answers to the questionnaire that is open, it can be the gist of the reply that the majority of respondents already led to obey the principle of the regulations are developed and used as a foundation in higher education, both in the area of core activities and the support activities (are managerial). Therefore, in this aspect of the law supremacy, if it continues to be developed consistently and socialized and indoctrinated consistently and was followed by a strong commitment by all internal stakeholders, the Good Governance or governance of higher education will be realized better.

\subsection{Aspects of Accountability}

Accountability is one of the important principles in GoodUniversity Governance. Moreover, it is a principle that was developed and implemented by public institutions, the issue of accountability is also emphasized for the delivery of higher education and university management, as stipulated in Government Regulation No. 4 of 2014, which states that in setting the college one of them should be held to public or public accountability. The level of accountability is measured by various parameters, among others, aspects akntabilitas illustrated with 5 indicators, including (1) The existence of a Standard Operating Procedure (SOP) in higher education; (2) The mechanism of accountability of higher education; (3) The annual report; (4) The accountability report of activities; (5) The control system of higher education. Each parameter measurements, the data analysis showed that on average $51 \%$ expressed approval of the accountability. This means that the level of accountability in the management of private universities is adequate although they should be improved continuously. Accountability is greatly supported by the level of availability and compliance with regulations and legislation that apply. This means that the level of accountability in the management of private universities is adequate although they should be improved continuously. Accountability is greatly supported by the level of availability and compliance with regulations and legislation that apply. This means that the level of accountability in the management of 
private universities is adequate although they should be improved continuously. Accountability is greatly supported by the level of availability and compliance with regulations and legislation that apply.

\subsection{Aspects of Effectiveness}

Based on the research that has been done in some private university in Medan, the aspect of effectiveness is measured by several parameters, including (1) The existence of a Standard Operating Procedure (SOP) in higher education; (2) The mechanism of accountability of higher education; (3) The annual report; (4) The accountability report of activities; (5) There Sistempengendalian higher education. Based on the results of the study, the level of effectiveness in the management of the college average - average of $86 \%$. Private university in Medan in the context of the effectiveness of higher education has been effective in higher education in organizing and managing the college.

This is measured by the parameters clarity of vision statement, mission, and goals; clarity achievement strategy; clarity of program accomplishments; and a balance between the program and budget. From the analysis of the research data, the majority agreed that the private university in Medan has to have clarity of vision, mission, target for the program, and the objectives to be achieved in the future; clarity of the strategy to achieve the vision, goals, programs and objectives that were defined; confidence between the plans with the results; and the balance between resource users with implementation of the program.

\section{Conclusion}

Based on the presentation and discussion as above, it can be summarized that the real Good Governance has been applied to private universities in Medan. Based on the results of statistical analysis, the majority of respondents expressed approval that transparency, participation, supremacy of law or regulatory compliance, akuntabulitas, and effectiveness is good. In detail, namely; Respondents expressed approval in the implementation of good governance in the private university in the city of Medan has implemented a transparency of $86 \%$, Respondents expressed approval in the implementation of good governance in the private university in the city of Medan have implemented aspects of the participation of $88 \%$, Respondents expressed approval in the implementation of good governance in the private university in the city of Medan have implemented aspects of the rule of law by $84 \%$, Respondents expressed approval in the implementation of good governance in the private university in the city of Medan has implemented the accountability of 51\%, Respondents expressed approval in the implementation of good governance in the private university in the city of Medan have implemented aspects of the effectiveness of $86 \%$.

\section{References}

[1] ADB Bank, A. D. (ADB) (2012) Administration and Governance of Higher Education in Asia.

[2] Connors, M. K. (2009) 'Liberalism, authoritarianism and the politics of decisionism in Thailand', Pacific Review, 22(3), pp. 355-373. doi: $10.1080 / 09512740903068396$.

[3] Cortese, A. D. (1997) 'The critical role of higher education in creating a sustainable future', Planning for Higher Education, 31(3), pp. 15-22. doi: 
10.1142/S1363919610003045.

[4] Davidovitch, N. and Iram, Y. (2015) 'Models of Higher Education Governance: A Comparison of Israel and Other Countries', Global Journal of Educational Studies, 1(1), p. 16. doi: 10.5296/gjes.v1i1.7556.

[5] Denis, D. K. and McConnell, J. J. (2002) 'International Corporate Governance', Ssrn, 38(1), pp. 1-36. doi: 10.2139/ssrn.320121.

[6] Kaufmann, D. et al. (2010) 'The Worldwide Governance Indicators: Methodology and Analytical Issues'. Available at: www.govindicators.org.

[7] Khan, H. (2011) 'A Literature Review of Corporate Governance', International Conference on E-business, Management and Economics, 25, pp. 1-5. doi: 2011.

[8] Matengu, K., Likando, G. and Kangumu, B. (2014) 'Governance and Coordination of the Higher Education System in Namibia: Challenges and Prospects', Forum for International Resource in Education, 1(2).

[9] McLendon, M. K. (Michael K., Deaton, S. B. and Hearn, J. C. (2007) 'The Enactment of Reforms in State Governance of Higher Education: Testing the Political Instability Hypothesis', The Journal of Higher Education, 78(6), pp. 645-675. doi: 10.1353/jhe.2007.0041.

[10] Pennock, L., Jones, G. A. and Leclerc, J. M. (2004) 'Challenges and opportunities for collegial governance at Canadian universities: Reflections on a survey of academic senates', Canadian Journal of Higher Education, 46(3), pp. 73-89.

Available

at: https://www.oise.utoronto.ca/hec/UserFiles/File/Challenges_and_Opportunities for_Collegial_Governance.pdf.

[11] Pfeiffer, J. J. and Jr, R. L. V. (1999) 'Spatial Query By Sketch Using Hue and Saturation for Result Visualization Gaia : Classification by Sketch', 2, pp. 1316. doi: 10.1787/9789264075375-en.

[12] Rowlands, J. (2011) 'Studies in Higher Education Academic boards: less intellectual and more academic capital in higher education governance?', 38(August 2013), pp. 37-41. doi: 10.1080/03075079.2011.619655.

[13] Sciences, A. (2007) 'The Impact of Corporate Governance Mechanisms on the Performance of UAE Firms: An Empirical Analysis Khaled Aljifri, PhD Mohamed Moustafa, PhD College of Business and Economics UAE University', Sciences-New York, 23(2), pp. 71-93.

[14] Sen, D. (2016) 'International Journal of Multidisciplinary Education and Research Higher education policies: The Indian experience since independence', International Journal of Multidisciplinary Education and Research, 1(10), pp. 15-21. Available at: www.educationjournal.in.

[15] Tom Christensen and Laegreid, P. (2007) 'The Whole-of-Government Approach to Public Sector Reform', Public Administration Review, 67(6), pp. 1059-1066. doi: 10.1111/j.1540-6210.2007.00797.x.

[16] FCGI, 2000 Good governance. Forum for Good Governance in Indonesia. Jakarta.

[17] NCG 2009, Code of Good Good governance Indonesia. Jakarta: The National Committee.

[18] OECD (2004), "Principles of good governance," Paris, France, OECD Publications Services.

[19] Bank Indonesia Regulation No. 8/4 / PBI / 2006 regarding Implementation of Good Good governance for Banks, LNRI 2006 Number 6 DPNP. 
